\title{
GENERAL TASKS AND AUTHORIZATIONS OF POICE INPRELIMINARY PROCEDURE IN
} KOSOVA

\author{
Murat Hulaj \\ St. Square "Mentor Tolaj" No. 8, Deçane, 51000, Kosovo \\ mhulaj@live.com, mobil: +377 44134009
}

Abstract

\begin{abstract}
The aim of this paper is to reflect the role of Police in preliminary procedure taking into consideration differences in judicialcriminal system of Kosovo, referring in particularity: Investigating role of police in preliminary procedure; Acts that should be undertaken pursuant law authorizations in case of criminal acts; Detaining of persons who are found at the scene of incident; Control foe scene of incident and police security; Informing of suspects toward their rights and finally; Drafting of penal indictment. We are witnesses of the practice toward collecting of acts not as stipulated by the law which cause later problems in the following procedures of Prosecutor and the Courts due to defining and verifying of criminal acts truth.
\end{abstract}

Keywords: role, investigation, control, detention, informing, authorizations

\section{Introduction}

1. Investigating the role of the police in the previous procedure

With changes in the criminal legal system of Kosovo last year made changes the role of the police in its start up procedure before penal (See the second to KPCC, 2012, Chapter II, Initial Actions Kosovo Police, Article 69 -83, pages 26-83).We application of new laws in Kosovo as well as many others institutions police encounter some obstacles but with the help of public prosecutors and intensive training was reached that very soon to start implementing the new legal procedures.

\section{Action that is authorized to undertake when committed an offense.}

Even with this new justice system in Kosovo police is located in a position to be on during investigation been watching but that applies in this case is guided and supervised by the state prosecutor, which restricts made since police large errors because it is known that the police is obliged to reported criminal offenses for their action and to inform and seek help from the public prosecutors.

So judicial police investigates currently investigates all crimes directed and supervised by the public prosecutor, which is clearly seen that role of police in investigative procedure is very important.

POLICE investigating offense and without delay takes the all measures in order to hide the concealment.

As soon as notified police of suspected criminal offense prosecuted ex officio, whether through the filing of a criminal or otherwise, without delay and not later than twenty-four hours of receiving the information, inform state prosecutor and as before the other reports and provides additional information. (The police is obliged to do in accordance with Article 70 parag.4 KPPRK-es, Nr.04/L-123 to dt.13 December 2012 promulgated by Decree No. DL-057-2012, dt.21.12.2012 from President of the Republic of Kosovo Atifete Jahjaga implementation by January 1, 2013)

The public prosecutor directs and supervises the work of the court police preliminary procedures of penal procedure.

According to Article 201 when there is reasonable suspicion that criminal act performed, prosecuted or at the request of the state prosecutor (Police) must initiate all necessary measures to find the perpetrator, to stop hiding and his aides to him, to stop their escape, to find and save tracks the offense, and to gather the necessary information.

To be able to perform all of these tasks is authorized police to undertakes certain actions (in accordance with Article 70, paragraph 1, of KPCC-es 2,3,4, year 2012, page 26/27) such as:

- $\quad$ To gather information from persons; 
- Perform temporary control of the vehicle, passengers and their baggage;

- To restrict movement in the special area for the time when this action is necessary;

- Undertake measures necessary to establish the identity of persons and objects;

- Be organized to control for determining the location of an individual or object being requested by sending letter-alignment.

- To check the presence of the person in charge of special facilities and premises of public bodies and to examine the special objects belonging to them.

- The confiscated items that must be taken under the criminal procedure code or serve as evidence in criminal proceedings.

- Be assured physical examination, the injured party in accordance with Section 192 of this code and undertakes measures and other actions required to by law.

For all these actions and other actions undertook specific police is authorized to compile the minutes (official note in the manner provided in Article 81 KPPK.vit 2012, page 29).

Police can photograph a person and take his fingerprints, if there reasonable suspicion that he has committed a criminal offense.(See: Article 76 paragraph 1 of KPCC-es, vit.2012, page 28)

The public prosecutor may authorize police to photograph published when it is necessary to establish the identity of the suspect and in other cases when will contribute to the effective implementation of the procedure. (Article 76, paragraph 2 , page 28)

If it is necessary to identify whose fingerprints are found in certain objects, mud police take fingerprints of persons with mud probably have had contact with such objects.

Police, with the assistance of a qualified doctor or nurse of the emergency cases themselves can collect samples (from Article 192, paragraph 4 of this code) by the suspect if it is urgent. The public prosecutor immediately informed to collect such samples.

Police can be asked by the suspect to question alcohol test or urine samples through the respiratory, the refusal of the suspect to provide evidence of these samples constitutes acceptable. The suspect must be informed in advance about this.

No sample should not be forcibly taken without a court order.

\section{Prohibition of persons found in the scene}

Article 72 of the Criminal Procedure Code in effect in Kosovo from 1 January 2013 page 27 provides:that persons found at the crime scene and which may provide important information can be stopped for as long as is necessary but not more than 6 hours, otherwise if you can not always be provided such information, is only when there other ways to put them to proof.

Here one should be careful that it's probably not stopping passes general rule because it is contrary to various conventions on the protection of human rights. So care should be taken that it stops to be exceptional when other means.

Obtaining information from the police in all phases must keep in mind the rights of suspects and dared not be threatened or be offered something illegal to provide information, are null and void all the evidences collected by force or threat. Said one word must not violate the law to enforce the law.

\section{Checking safety officer}

Section 204 provides authority for the control of the interim police security if there is suspicion that the person has such weapons or dangerous items that can be used for attack or defense. This control should perform same-sex police with the suspect, but if the police can not ensure that same sex then I may exceptionally be carried by every cop (Article 75 paragraph 3 of page 28 of KPCC-es, the year 2012),but you must take care not to slip this general rule because human rights. Police photographed the suspects may be, to take fingerprints, collect samples, and to require suspects to undergo the alcohol test. If I suspect refuses to undergo a blood alcohol measurement then this evidence is sufficient. 


\section{Notice of suspects their rights}

Every person arrested, suspected or accused of committing a criminal offense is presumed innocent until verified his innocent final judgment.

A person suspected of or charged with criminal act has the right to demand fair criminal proceedings to enforce reasonable time. But the rights of the arrested person are clearly defined in the PCPC. A person arrested under PCPC that I have the following rights: where for each right will reflect that what is more important, in terms of procedural and local Laws in international (Convention, Article $3,4,5$ ) that are in endorsed the implementation implemented.

\section{A person arrested under PCPC that I have the following rights:}

\subsection{The right to notice of the reasons for arrest}

The arrested person has the right to be informed of the reasons for arrest in a language that he or she understands. That means that the person has the right to know why he was arrested, for which offense is doubtful (See Article 125, paragraph 3 of KPCC-es, page 56). Language of talking and listening between law enforcement bodies and the person arrested is not defined. There is only one condition must be language, which no doubt caught the person understands.

\subsection{The right to silence}

The arrested person has the right to remain silent and not answer any questions, besides giving information about the identity of his / her. He or she has the right to silence and not to give any statement;

He or she must show that he or she does not need to be introduced to protect them or to respond to questions submitted to them. The arrested person must identify himself and the police should carry identification procedure.

Whenever a person is arrested to be interviewed (for the first time or repeatedly), he or she firstly has to be informed of the right to silence. The suspects must be advised of their right to silence always before they are questioned in a legal manner.

- During the interrogation of the arrested person become regular breaks at intervals of approximately 2 hours. Leave may be extended when there is reasonable grounds to believe that the delay will be:

- risk of harm to persons or loss of serious damage to property;

- postpone detaining a person without need or finishing interrogation-or

- Otherwise prejudice the outcome of the investigation.

- During interrogation the arrested person is not required to stand on foot and is denied food, water and necessary medical care.

\subsection{The right to the aid of a translator}

The arrested person has the right to free assistance of an interpreter if he or she does not understand or speak the language of the police. This right is an obligation for law enforcement to provide arrested person be provided with free assistance of an interpreter if he or she does not understand the language of the police. This should be regulated in the public-spending state.

\subsection{The right to legal assistance}

The arrested person has the right to assistance of defense counsel of his choice after his or her arrest. If the person arrested can not pay legal aid lawyer will be provided by the police. The arrested person has the right to a lawyer during all interviews conducted by law enforcement authorities.

Law enforcement bodies will help or spaces provide the arrested person contacted the defense attorney. 
When ever an arrested person to be interviewed, he or she will be informed of the right to silence and the right to a lawyer.

The arrested person has the right to communicate reliably with defense counsel orally and in writing. Communication between the detainees and defender his or her may be made in view of law enforcement authorities are not to be heard (See Article 166, paragraph 3 KPCC, year 2012, page 75).

\subsubsection{Attorney Home}

If your lawyer does not appear within 2 hours of being informed of the arrest, law enforcement bodies will customize (provide) a defense attorney for detainee alternative. After that, if counsel alternative does not appear for an hour after he was approached by authorities of Internal Affairs, the person arrested may interviewed only when the public prosecutor or police glory of the further delay would seriously damage the investigation.

The arrested person has the right to the confidential communicates with his protection orally and in writing. This can be observed its communication by the police.

\subsubsection{Waiver of the right to assistance of defense counsel}

Protection of the right may be waived except in the case of protection required if the waiver is made clear, in an informed voluntary. A waiver must be in writing and signed by the suspect or the defendant and the competent authority conducting the proceedings or made orally on audio or video tape, whose authenticity is verified by the court.

When the suspect or defendant who has waived the right to defense requires commitment again this right, he can exercise this immediately. If the suspect or defendant commits no defense, his legal spouse or spouse Outside blood-sex person at a tangent, Adaptive parent, adopted child, brother , sister or foster can be deployed for defense but not against his will.

\subsection{2 a Protection of Minors}

Persons under 18 years may waive their right to defense committed with the consent of a parent, guardian or authorized representative of the center for social work besides domestic violence cases in which the parent or guardian is involved in which the parent or guardian does not may consent to the waiver of this right. [persons who show signs of disturbance or mental disability can not waive the right to defense commitment.

\subsection{2 b Forced Protection}

During interrogation the defendant has defense when: from getting the questions for the first time when the defendant is mute, deaf or displays signs of disturbance or disability and so is unable to defend himself or herself;

During their interrogation in custody and during the time while he is in custody;

From the filing of the indictment when the indictment was filed against him for the offense for which the sentence may be imposed at least 8 years prison proceedings under the emergency law when the defendant is mute, deaf or displays signs of disturbance or mental disability or been sentenced to long term imprisonment.

\subsection{2 $\mathrm{c}$ The right to notify family, embassy or other person designated}

The arrested person has the right to be informed or asked the police to notify family quote or any other person selected by his / her because of the arrest and place of detention immediately after arrest and for every subsequent change of the place of detention immediately after the change of the place of detention.

\section{Compilation of criminal denunciation}

No matter what manner we have come to information through denunciation by citizens or through information collected during the performance of routine police duties after having accumulated sufficient evidence compiles the charge. A 
criminal report compiled by the police is finalization of police work in connection with the investigation of specific criminal offense. The other form of criminal compilation police public prosecutor submitted together with objects, sketches, photographs, reports received, statements, records etc (in accordance with Article 81 paragraph 1 and 2 of the KPCC, page 29). If after compiling criminal denunciation to the police, the police comes to new facts or new evidence and the police is obliged to facts supplementary report sent to the public prosecutor (Under section 81 paragraph 3 of the KPCC, page 30).If after investigation the police conducted ng the results that there is sufficient basis to frame criminal charges then again the police were forced back to the public prosecutor announced a separate report, in connection with their actions (in accordance with paragraph 4 of Article 81 of the KPCC, also page 30).

\section{Summary}

Given what was said above once the police receives information that an offense has been committed it investigates the possible perpetrator of that offense, undertakes all measures necessary to gather evidences. Here you should consider the fact that not enough to know that someone has committed a criminal offense but it must demonstrate that it is the perpetrator of this must be done by presenting evidence that showed that the suspect has committed the offense really. During data collection the main purpose of the police is their investigation ended with criminal charges based on the facts and the criminal charges that resulted in an indictment by the public prosecutor. Also the purpose of the police is execution perpetrators of offenses punished, cure those who are innocent do not suffer from the actions of the police.

\section{References}

[1] See the second to KPCC, 2012, Chapter II, Initial Actions Kosovo Police, Article 69 -83, pages 26-83

[2] This police is obliged to do in accordance with Article 70 parag. 4 KPPRK-es, Nr.04/L-123 to dt.13 December 2012 promulgated by Decree No. DL-057-2012, dt.21.12.2012 President of the Republic of Kosovo Atfete Jahjaga, the implementation of 01.janari 2013)

[3] Accordance with Article 70, paragraph 1, of KPCC-es 2, 3, 4, year 2012, page 26/27

[4] The official record in the manner provided in Article 81 KPPK.vit 2012, page 29

[5] See Article 76, paragraph 1 of KPCC-es, vit.2012, page 28

[6] Article 76, paragraph 2, paage 2

[7] Aaccording to Article (76 paragraph 4 of KPCC-es, page 28

[8] Article 72 of the Criminal Procedure Code in effect in Kosovo from 1 January 2013 page 27 provides:

[9] Article 75 paragraph 3 of KPCC-es, the year 2012 page 28

[10] See Article 125, paragraph 3 of KPCC-es, page 56)

[11] See Article 166, paragraph 3 KPCC, year 2012, page 75

[12] In accordance with Article 81 paragraph 1 and 2 of the KPCC, page 29

[13] Under section 81 paragraph 3 of the KPCC, page 30

[14] In accordance with paragraph 4 of Article 81 of the KPCC, also page 30

[15] Dr.sc. Xhemajl Ademaj, crime scene investigations in criminal, Third Edition, Pristina, 2003.

[16] Dr.sc. Azem Hajdari, Criminal Procedure Commentary, Prishtina 2010

[17] Ave. Eyup Sahiti, Criminal Procedure Law, Pristina 2005

[18] Ave. Ismet Salihu Criminal Law, Juvenile Criminal Law for minors, Prishtina 2005

[19] Code of Criminal Procedure of 2004 and that of 2013

[20] European Convention on Human Rights 
